\title{
INVESTIGASI AIR TANAH BERDASARKAN NILAI RESISTIVITAS DI DUSUN JATISARI, KABUPATEN LAMPUNG SELATAN
}

\section{GROUNDWATER INVESTIGATION BASED ON THE RESISTIVITY VALUE IN JATISARI VILLAGE, SOUTH LAMPUNG}

\author{
Andri Yadi Paembonan ${ }^{1 *}$, Purwaditya Nugraha ${ }^{2}$, Nono Agus Santoso ${ }^{3}$, Ruhul Firdaus ${ }^{4}$, Gestin \\ Mey Ekawati ${ }^{5}$, Virgian Rahmanda ${ }^{6}$, Felik Destian Putra Amijaya ${ }^{7}$ \\ 1,2,3,4,5,6,7 Institut Teknologi Sumatera; Jl. Terusan Ryacudu, W ay H ui, Kecamatan Jati A gung, Lampung \\ Selatan 35365; (0721) 8030188
}

Received: 2020, N ovember $20^{\text {th }}$ Accepted: 2021, April 09 $9^{\text {th }}$

\author{
Keyword: \\ Aquifer; \\ Groundwater; \\ Resistivity; \\ VES.
}

\section{Corespondent Email:}

andri.paembonan@tg.itera.ac.id

\section{H ow to cite this article:}

Paembonan, A.Y., Nugraha, P., Santoso, N.A., Firdaus, R.,

Ekawati, G.M., Rahmanda, V., $\&$ A mijaya, F.D.P. (2021).

Investigasi Air Tanah

Berdasarkan Nilai Resistivitas
Abstrak. Air tanah adalah sumber air tawar terbesar yang tersedia. Air tanah ini sangat penting untuk kehidupan manusia maka dari itu perlu adanya identifikasi zona air tanah yang potensial sebagai salah satu solusi untuk krisis air bersih. Namun pada sebagian daerah sangat sulit untuk menemukan air tanah yang baik karena disebabkan oleh kondisi geologi yang kompleks. Penelitian ini bertujuan untuk mendapatkan informasi keberadaan air tanah dari variasi nilai resistivitas bawah permukaan dengan menggunakan metode Vertical Electrical Sounding (VES) di wilayah Dusun Jatisari, Desa Jatimulyo, Kecamatan Jati Agung, Lampung Selatan. Keberadaan air tanah umumnya memiliki nilai resistivitas rendah hingga sedang. Oleh karena itu, hasil dari penelitian ini akan sangat membantu masyarakat dalam mengetahui kedalaman zona jenuh air (akuifer) untuk mendapatkan air bersih. Dari hasil yang diperoleh terlihat bahwa air tanah dengan rentang nilai resistivitas 10 - $35 \mathrm{Ohm}$.m berada pada kedalaman yang berbeda-beda. Pada titik VES PKM_S1, PKM_S2, dan PKM_S3 lapisan akuifer berada pada kedalaman $7.5 \mathrm{~m}$, sedangkan titik VES PKM_S4 berada pada kedalaman $36 \mathrm{~m}$, dan titik VESPKM_S5 berada pada kedalaman $8.5 \mathrm{~m}$.

Abstract. Groundwater is the largest source of fresh water available, so it is necessary to identify potential groundwater zones as a solution to the clean water crisis. Unfortunately, in some areas it is very difficult to find good groundwater due to complex geological conditions This study aims to obtain the groundwater information from the subsurface resistivity variations using 
di Dusun Jatisari, Kabupaten Lampung Selatan. Jurnal Geofisika Eksplorasi, 07(02), 100-110.

(c) 2021 JGE (Jurnal Geofisika Eksplorasi). This article is an openaccess article distributed under the terms and conditions of the Creative Commons Attribution (CC BY NC) the Vertical Electrical Sounding (VES) method in the Jatisari Hamlet, Jatimulyo Village, Jati Agung District, South Lampung. The presence of groundwater generally has a low to moderate resistivity value. Therefore, the results will greatly assist the community in knowing the depth of the watersaturated zone(aquifer) to get clean water. The results show that groundwater depth in the study area has a resistivity value range from 10 to $35 \mathrm{Ohm} . \mathrm{m}$ at different depths. At the VES PKM_S1, PKM_S2, and PKM_S3, the aquifer layer is at a depth of $7.5 \mathrm{~m}$, while the VES PKM_S4 is at a depth of $36 \mathrm{~m}$, and theVES PKM_S5 point is at a depth of 8.5 .

\section{PENDAHULUAN}

Air merupakan kebutuhan yang sangat penting bagi mahkluk hidup. Manusia dan mahluk hidup lainnya sangat membutuhkan air untuk hidup. Manusia memanfaatkan air sebagai air minum, mencuci, mandi dan kebutuhan lainnya. Di antara sumber air yang ada, sumber air yang banyak digunakan oleh masyarakat adalah air permukaan (sungai, waduk, rawa), air tanah, dan air hujan. Sementara dengan semakin bertambahnya populasi dan semakin rusaknya lingkungan, sumber air permukaan yang memenuhi syarat sebagai air bersih jumlahnya semakin hari semakin berkurang. Faktor lain yang menyebabkan kelangkaan air yaitu polusi dari limbah rumah tangga maupun pabrik dan penggunaan air yang berlebihan (Asmadi \& Suharno, 2012). Jarak ke sumber air yang jauh, dan kekeringan juga menjadi faktor dari krisis air bersih.

Krisis air bersih dapat diselesaikan dengan melakukan beberapa tahapan penting, seperti memperbaiki infrastruktur, pemanfaatan air tanah (groundwater) dan pemulihan akuifer, melakukan riset dan penggunaan teknologi, mengontrol polusi dan kontaminasi, konservasi air, membuat sistem tadah hujan, meningkatkan kesadaran dan pendidikan masyarakat dan lain-lain. Air tanah adalah sumber air tawar terbesar yang tersedia, maka perlu untuk mengidentifikasi zona air tanah yang potensial sebagai salah satu solusi untuk krisis air bersih.

Metode resistivitas adalah yang paling populer dari semua metode geofisika untuk eksplorasi air tanah (Paembonan dkk., 2020; Hewaidy dkk., 2015; M ohamaden dkk., 2016; Mohamaden \& Shagar, 2008). Metode ini digunakan dengan memanfaatkan sifat tahanan listrik batuan atau material lainya. $\mathrm{Hal}$ ini berkaitan dengan aliran arus listrik melalui material itu. Tahanan listrik sedimen atau batuan adalah fungsi dari porositas, saturasi, resistivitas cairan pori dan fase padat, dan tekstur bahan. Nilai resistivitas dan konduktivitas batuan terkait dengan berbagai karakteristik geologi pada suatu daerah. Beberapa hal yang mempengaruhi resistivitas atau konduktivitas batuan yaitu mineral yang terkandung dalam batuan, fluida, porositas dan derajat saturasi air pada batuan (Loke, 2016). Pada Gambar 1 ditampilkan beberapa jenis batuan dan fluida beserta nilai resistivitasnya. Umumnya batuan beku dan metamorf cenderung memiliki nilai resistivitas yang tinggi, sebaliknya batuan sedimen biasanya memiliki nilai resistivitas rendah bila dibandingkan dengan batuan beku dan metamorf. Hal ini dikarenakan tektur batuan sedimen memiliki nilai porositas yang tinggi dan cenderung meresap air (Telford dkk., 1990). 


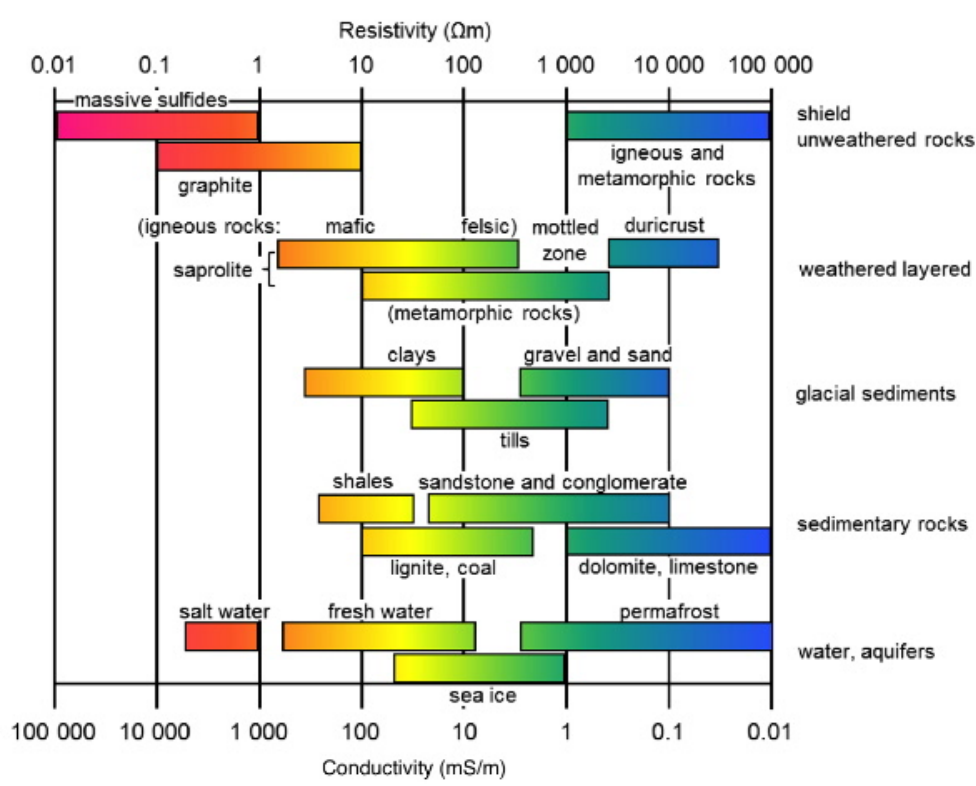

Gambar 1. Nilai resistivitas dan konduktivitas beberapa jenis batuan dan fluida (Palacky, 1988).

Kondisi geologi bawah permukaan yang didominasi oleh lapisan batuan dengan kompleksitas yang tinggi dapat salah satu faktor yang menyebabkan sulit untuk menemukan air tanah yang baik. $\mathrm{H}$ al ini yang terjadi di sebagian Dusun Jatisari, Desa Jatimulyo, Kecamatan Jati Agung, Lampung Selatan (Gambar 2) yang didominasi oleh lapisan batuan tufa yang cukup tebal dengan fragmen berupa pasir dan lempung. Pada penelitian ini digunakan metode geofisika, resistivitas tahanan jenis untuk menentukan keberadaan air tanah yang layak untuk digunakan. Survei dengan metode resistivitas tahanan jenis memberikan informasi dari variasi nilai resistivitas bawah permukaan yang erat kaitannya dengan keberadaan air tanah sebelum dilakukan pengeboran. Oleh karena itu, upaya ini akan sangat membantu dalam mengetahui kedalaman zona jenuh air (akuifer) untuk mendapatkan air bersih.

\section{TINJAUAN PUSTAKA}

Setiap batuan memiliki sifat kelistrikan yang berbeda-beda. Terdapat beberapa faktor yang mempengaruhi sifat kelistrikan batuan diantaranya adalah mineral-mineral dan struktur batuan yang mengakibatkan batuan bersifat konduktif atau resistif apabila dialirkan arus listrik kedalamnya. Sifat listrik ini dapat terjadi secara natural dan berasal dari arus listrik yang diinjeksikan yang menyebabkan terjadinya ketidak-seimbangan muatan (Hendrajaya \& Idham, 1990).

Resistivitas sebuah material merupakan parameter yang menunjukan tingkat hambatan terhadap arus listrik yang berbanding terbalik dengan nilai konduktifitas yang merupakan kemampuan suatu material untuk menghatarkan listrik. M aterial yang memiliki nilai resistivitas besar, akan semakin sukar untuk dilalui arus listrik, begitupun sebaliknya.

$M$ etode resisitivitas adalah metode geofisika yang digunakan untuk mengetahui kondisi bawah permukaan berdasarkan perbedan resistivits batuan. Resistivitas batuan bervariasi menurut jenis batuan karena jenis mineral penyusunnya, porositas, dan permeabilitas, serta kandungan fluida. Berdasarkan sifat konduktifitasnya, batuan mineral dapat dikelompokkan menjadi konduksi elektronik, 
konduksi elektrolitik dan konduksi dielektrik (Telford dkk., 1990).

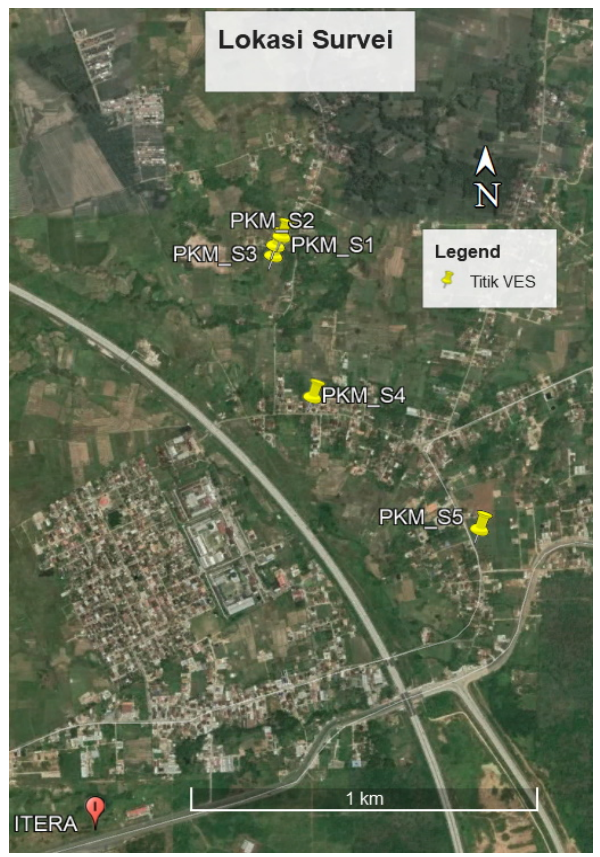

Gambar 2. Lokasi penelitian di Dusun Jatisari, Desa Jatimulyo, Kecamatan Jati A gung, Lampung Selatan. Terlihat 5 titik pengukuran VES.

Pada prinsipnya pengukuran dengan metode resistivitas dilakukan dengan menginjeksikan arus listrik melalui elektroda C1 dan C2 dan mengukur responnya dengan mengukur beda potensial pada elektroda P1 dan P2. Beda potensial dapat dihitung dengan:

$$
\begin{aligned}
\Delta V & =V_{p 1}-V_{p 2} \\
& =\frac{I \rho}{2 \pi}\left(\frac{1}{r_{1}}-\frac{1}{r_{2}}-\frac{1}{r_{3}}+\frac{1}{r_{4}}\right)
\end{aligned}
$$

dimana $\mathrm{V}$ adalah poternsial (Volt), I merupakan besarnya arus yang diinjeksikan (Ampere), $\rho$ merupakan resistivitas (Ohm.meter), $\mathrm{r}$ adalah jarak electroda arus (meter) dan potensial serta $\pi$ adalah konstanta dengan nilai 3.34. Dari persamaan diatas dapat ditulis menjadi:

$$
\rho=K \frac{\Delta V}{I}
$$

dimana $K$ merupakan faktor geometri yang dituliskan sebagai berikut:

$$
K=2 \pi\left(\frac{1}{r_{1}}-\frac{1}{r_{2}}-\frac{1}{r_{3}}+\frac{1}{r_{4}}\right)^{-1}
$$

\subsection{Konfigurasi Schlumberger}

Pengaturan letak elektroda pada metode ini terdapat beberapa variasi yang biasa disebut konfigurasi elektroda, salah satunya adalah konfigurasi Schlumberger. Pengukuran dengan konfigurasi ini menggunakan 4 elektroda, masing-masing 2 el ektroda arus dan 2 el ektroda potensial dapat dilihat pada Gambar $\mathbf{3}$.

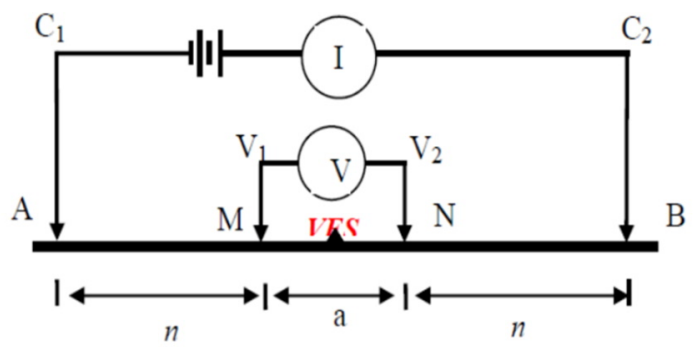

Gambar 3. Susunan Elektroda Konfigurasi Schlumberger (Dimodifikasi dari Loke, 2016).

Pada konfigurasi Schlumberger, jarak elektroda potensial $M N$ tetap sedangkan jarak elektroda arus $A B$ diubah-ubah. Karena keterbatasan kepekaan alat ukur, maka ketika jarak $A B$ relatif lebih besar maka jarak $M N$ seharusnya diubah.

Untuk memperoleh tahanan jenis semu medium yang terukur, maka dapat dihitung berdasarkan persamaan (2) dengan nilai $\mathrm{K}$ tergantung penempatan elektroda di permukaan yang besarnya:

$$
\mathrm{K}=2 \pi\left[\left(\frac{1}{\mathrm{AM}}-\frac{1}{\mathrm{MB}}\right)-\left(\frac{1}{\mathrm{AN}}-\frac{1}{\mathrm{NB}}\right)\right]^{-1}
$$

Dimana AM, BM, AN, dan BN merupakan jarak antar elektroda.

Keunggulan konfigurasi Schlumberger ini adalah pada umumnya hanya elektroda luar $\mathrm{A}$ dan $B$ yang perlu sering dipindahkan. O perator yang terdiri dari tiga orang biasanya cukup, dengan dua orang menggerakkan elektroda luar, dan operator instrumen biasanya yang memindahkan elektroda dalam $\mathrm{M}$ dan $\mathrm{N}$. Untuk mendeteksi adanya non-homogenitas 
lapisan batuan dapat dilakukan dengan membandingkan nilai resistivitas ketika terjadi perubahan jarak elektroda MN/2. Perubahan jarak elektroda MN terhadap jarak elektroda AB dilakukan ketika pembacaan tegangan listrik pada multimeter sudah demikian kecil (Robinson, 1998).

\subsection{Geologi Daerah Penelitian}

Lokasi penelitian berada padan pada Peta Geologi Lembar Tanjung Karang pada Formasi Lampung (Qtl) dengan umur Kuarter. Formasi ini mendominasi hampir seluruh wilayah pada Lembar Tanjung Karang (Gambar 4) dan tersebar luas di bagian Timur dan Timur Laut dengan ketebalan mencapai 500 meter. Batuan yang mendominasi formasi ini terdiri dari batuan riolit-tufan dan vulkanoklastik tufan yang terdiri dari tuf berbatu apung, tuf riolitik, tuf padu tufit, batu lempung tufan dan batu pasir tufan. Lingkungan pengendapannya berada pada lingkungan terestrial-fluvial air payau dan menindih tak selaras pada batuanbatuan yang lebih tua (M angga dkk., 1993).

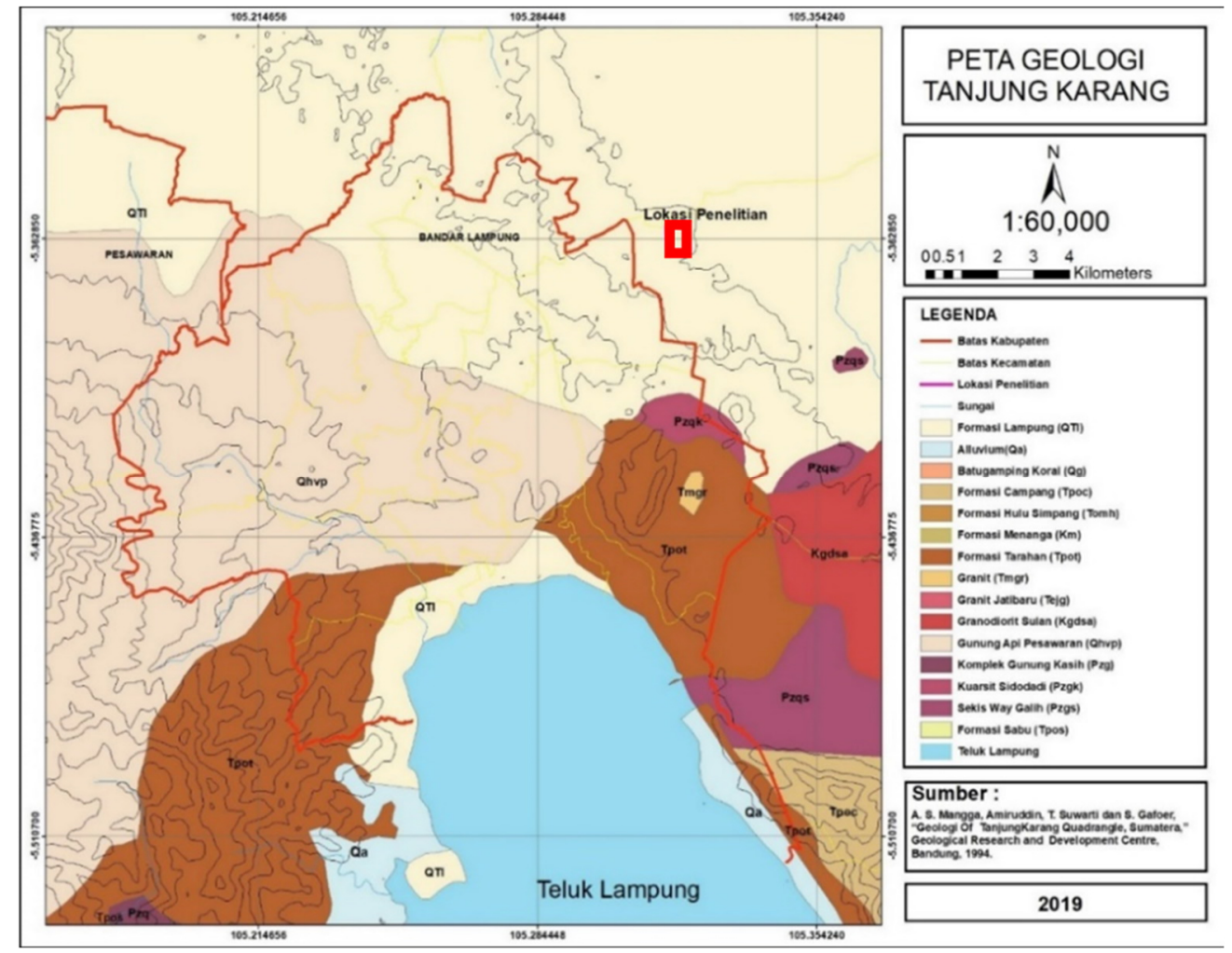

Gambar 4. Peta geologi daerah penelitian (modifikasi dari Mangga dkk., 1993).

\section{METODE PENELITIAN}

Metode resistivitas

umumnya menempatkan elektroda secara linear, dengan titik pengukuran di tengahnya. Orientasi penyebaran elektroda harus serata mungkin untuk mengasumsikan Bumi yang berlapis secara horizontal (Aizawa, 2014).

Pada penelitian ini, akuisisi data dilakukan dengan menggunakan konfigurasi Sclumberger pada 5 titik yang berbeda. Jarak elektroda arus terjauh (AB) bervariasi dari 150 meter sampai 300 meter, sehingga kedalaman yang diperoleh juga berbeda. Hal ini dikarenakan kondisi lokasi pengambilan data yang berada di pemukiman penduduk. Data yang diperoleh kemudian diolah dan menghasilkan variasi nilai resistivitas terhadap kedalaman. Selanjutnya dilakukan interpretasi terhadap data yang diperoleh dengan mengacu pada informasi lain yang didapatkan, seperti geologi daerah 
penelitian dan hasil interpretasi dari penelitian sebelumnya.

\section{HASIL DAN PEMBAHASAN}

Penelitian ini terletak di wilayah geologi Formasi Lampung dengan litologi batuan yang didominasi oleh batuan tuf. Secara umum tufa memiliki nilai resistivitas yang relatif tinggi, namun pada kondisi tertentu tuf dapat memiliki nilai resistivitas yang rendah. Beberapa hal dapat disebabkan oleh kondisi tersebut seperti faktor saturasi air yang terdapat pada tubuh batuan. Pada Tabe $\mathbf{1}$ berikut ini adalah klasifikasi nilai resistivitas batuan di sekitar daerah penelitian yang telah dipelajari dan dijadikan acuan dalam proses interpretasi data (Rizka \& Satiawan, 2019).

Tabel 1. Nilai resistivitas batuan sekitar daerah penelitian berdasarkan penelitian sebelumnya (Rizka \& Satiawan, 2019).

\begin{tabular}{ccc}
\hline No & Jenis Batuan & $\begin{array}{c}\text { Nilai Resistivitas } \\
\text { (Ohm.m) }\end{array}$ \\
\hline 1 & Lempung tufan & $<20$ \\
\hline 2 & Tuf pasiran & $20-80$ \\
\hline 3 & Tuf & $80-150$ \\
\hline 4 & Tuf & $>150$ \\
\hline
\end{tabular}

Selain data dari penelitian sebelumnya, informasi yang diperoleh dari warga sekitar terkait kedalaman air tanah juga sangat membantu dalam melakukan interpretasi. Dari informasi yang diperoleh, kedalaman sumur warga berkisar dari 10 -12 meter.

Berdasarkan hasil pengukuran VES yang dilakukan pada titik PKM_S1 (Gambar 5), diperoleh 3 lapisan dengan variasi nilai resistivitas yang berbeda. Pada pengukuran ini terlihat pada lapisan pertama dengan kedalaman $7.5 \mathrm{~m}$ ditemukan adanya lapisan top soil dengan nilai resistivitas rendah 4.34 Ohm.m, kemudian di bawahnya ditemukan lapisan batuan tuf pasiran dengan nilai resistivi tas 10-30 Ohm.m dengan ketebalan lapisan 12.6 m pada kedalaman sampai dengan 20 meter. Kemudian lapisan di bawahnya ditemukan lapisan lempung tufan dengan nilai resistivitas yang lebih rendah dengan nilai $1.9 \mathrm{Ohm} . \mathrm{m}$ dengan ketebalan lapisan kurang lebih $34 \mathrm{~m}$.

Pada titik pengukuran 1 ini dapat terlihat bahwa nilai resistivitas yang didapatkan cenderung lebih rendah dikarenakan pengukuran dilakukan pada waktu musim hujan. Dari nilai resistivitas yang didapatkan kemudian dilakukan interpretasi dan didapatkan bahwa akuifer dari air tanah dapat ditemukan di lapisan kedua dengan litologi batuan tuf pasiran dengan ketebalan $12.6 \mathrm{~m}$. Sedangkan lapisan di bawahnya yang berupa lempung tufan yang mempunyai resistivitas rendah yang kemungkinan merupakan lapisan akiklud dari akuifer air tanah yang diidentifikasi.

Pada titik pengukuran VES PKM_S2 (Gambar 6), juga didapatkan 3 perlapisan dengan nilai resistivitas yang berbeda. Dari hasil terlihat pada kedalaman $7.5 \mathrm{~m}$ ditemukan adanya lapisan top soil dengan nilai resistivitas $3.680 \mathrm{hm}$.m kemudian di bawahnya ditemukan batuan tuf pasiran dengan nilai resistivitas 10 30 O hm.m dengan ketebalan lapisan $12.6 \mathrm{~m}$ sampai pada kedalaman sampai dengan 20 meter. Pada lapisan ke-3 ditemukan lapisan lempung tufan dengan nilai resistivitas yang lebih rendah dengan nilai $3.73 \mathrm{Ohm} . \mathrm{m}$ dengan ketebalan lapisan kurang lebih 34 meter.Pada titik VESPKM_S2 ini dapat terlihat bahwa nilai resistivitas yang didapatkan cenderung rendah dikarenakan pengukuran dilaksanakan pada musim. Zona akuifer dari air tanah dapat ditemukan di lapisan kedua dengan litologi batuan tuf pasiran dengan ketebalan. Sedangkan lapisan di bawahnya yang berupa lempung tufan kemungkinan merupakan lapisan akiklud. 


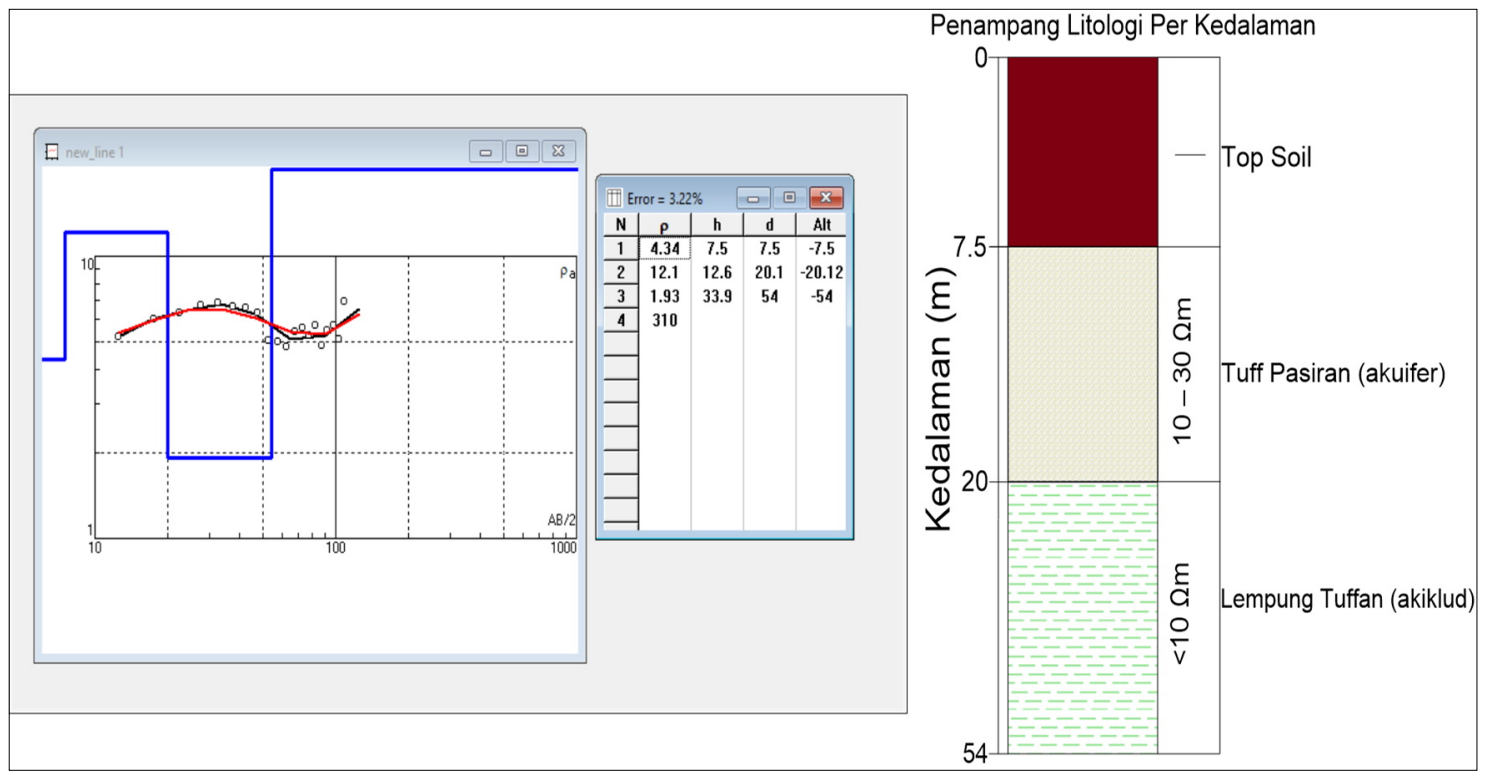

Gambar 5. Hasil pengukuran dari titik PKM_S1 memperlihatkan model resistivitas pada gambar sebelah kiri dan hasil interpretasi pada gambar sebelah kanan.

Pada titik pengukuran ini terlihat bahwa nilai resistivitas sedang diinterpretasikan sebagai akuifer dari air tanah dapat ditemukan di lapisan kedua dengan litologi batuan tuf pasiran dengan ketebalan $14.4 \mathrm{~m}$. Sedangkan lapisan di bawahnya berupa lempung tufan kemungkinan merupakan lapisan akiklud dari akuifer air tanah yang diidentifikasi.

Gambar 8 memperlihatkan kedalaman akuifer yang sama. Ketiga titik VES tersebut, PKM_S1, PKM_S2 dan PKM_S3, masing masing berjarak kurang lebih $30 \mathrm{~m}$. Ketiga titik tersebut kemudian dikorelasikan (Gambar 8) untuk melihat kemenerusan dari lapisan yang ada. Dari ketiga titik tersebut memperlihatkan bahwa kedalaman lapisan akuifer berada pada kedalaman yang sama yaitu $7.5 \mathrm{~m}$.

Titik pengukuran VES PKM_S4 (Gambar 9), juga didapatkan 3 perlapisan dengan nilai resistivitas rendah samapai moderat. Lapisan top soil ditemukan pada kedalaman $7.5 \mathrm{~m}$ dengan nilai resistivitas 16.9 Ohm.m. Lapisan berikutnya ditemukan lapisan lempung tufan dengan nilai resistivitas yang lebih rendah dengan nilai 5.82 Ohm.m dengan ketebalan lapisan kurang lebih $28 \mathrm{~m}$. Lapisan batuan tuf pasiran dengan nilai resistivitas 10-30 0 hm.m dengan ketebalan lapisan $41.32 \mathrm{~m}$ pada kedalaman sampai dengan $76.7 \mathrm{~m}$ ditemukan pada lapisan ketiga. Nilai resistivitas pada lapisan pertama cenderung lebih tinggi dikarenakan pada saat pengukuran kondisi cuaca cerah. Pada penampang dapat diinterpretasikan bahwa akuifer dari air tanah dapat ditemukan di lapisan ketiga dengan litologi batuan tuf pasiran dengan ketebalan $41.2 \mathrm{~m}$. Dengan lapisan lempung tufan yang berada di atasnya diidentifikasi sebagai lapisan akiklud.

VES PKM_S4 (Gambar 9), didapatkan adanya 3 buah perlapisan dengan nilai resistivitas yang bergam. Dari permukaan sampai pada kedalaman $8.5 \mathrm{~m}$ ditemukan adanya lapisan top soil dengan nilai resistivitas 107 O hm.m, kemudian di bawahnya ditemukan lapisan batuan tuf pasiran dengan nilai resistivitas 10-30 Ohm.m dengan ketebalan lapisan $28.7 \mathrm{~m}$ padakedalaman sampai dengan 
36.4 m. Kemudian lapisan di bawahnya ditemukan lapisan lempung tufan dengan nilai resistivitas yang lebih rendah dengan nilai 3.05
Ohm.m dengan ketebalan lapisan kurang lebih $80 \mathrm{~m}$.

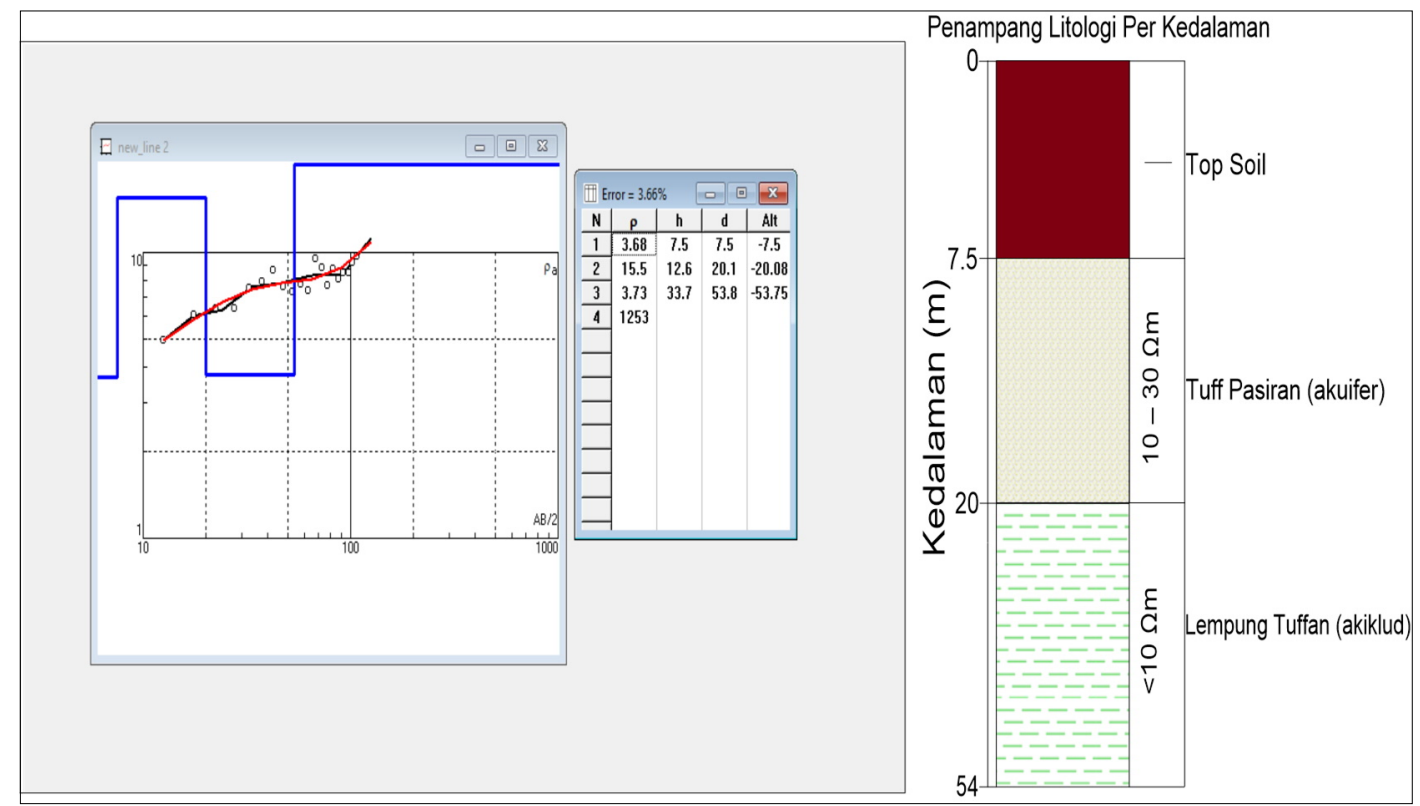

Gambar 6. Hasil pengukuran dari titik VESPKM_S2 memperlihatkan model resistivitas pada gambar sebelah kiri dan hasil interpretasi pada gambar sebelah kanan.

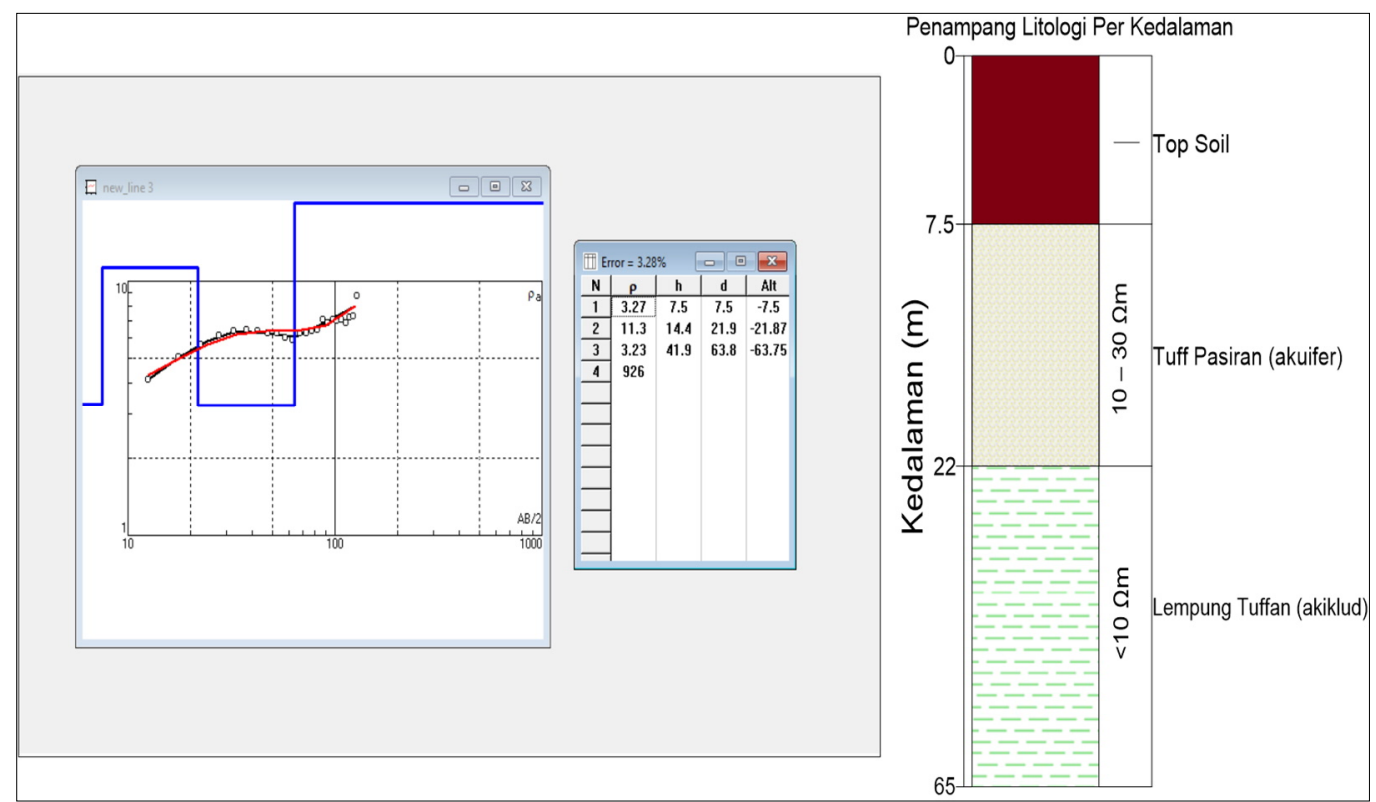

Gambar 7. Hasil pengukuran dari titik VES PKM_S3 memperlihatkan model resistivitas pada gambar sebelah kiri dan hasil interpretasi pada gambar sebelah kanan. 


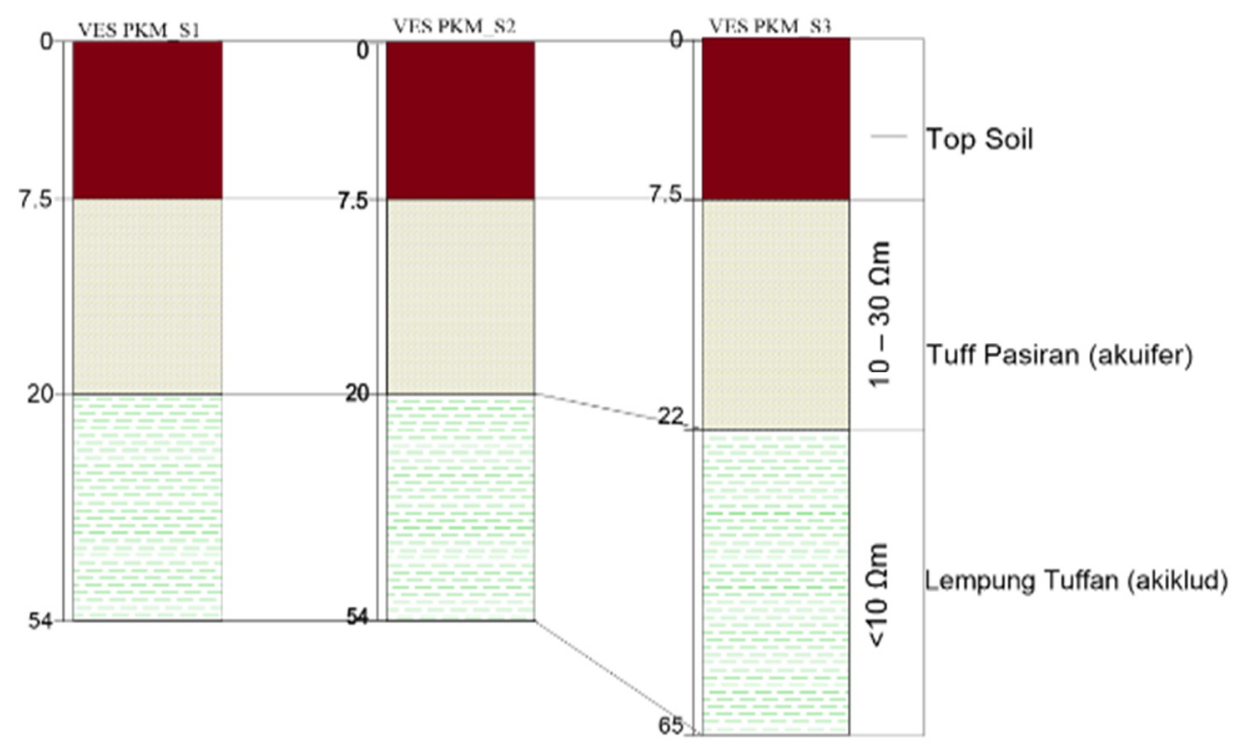

Gambar 8. Korelasi tiga titik pengukaran PKM_S1, PKM_S2 dan PKM_S3.

Dari hasil yang diperoleh pada Gambar $\mathbf{1 0}$ terlihat bahwa nilai resistivitas yang didapatkan cenderung lebih tinggi. Akuifer dapat ditemukan di lapisan kedua dengan litologi batuan tuf pasiran dengan ketebalan $28.7 \mathrm{~m}$.
Sedangkan lapisan di bawahnya yang berupa lempung tufan kemungkinan merupakan lapisan akiklud dari akuifer air tanah yang diidentifikasi.

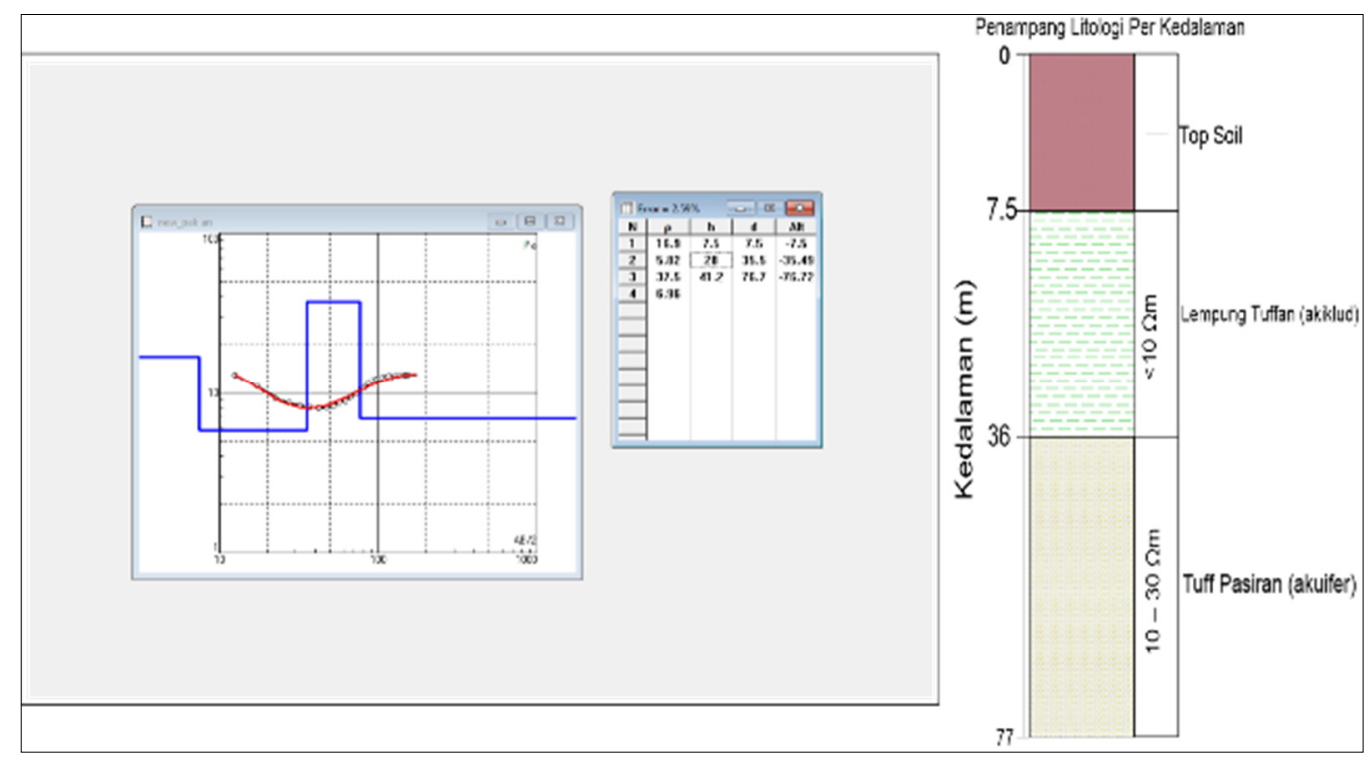

Gambar 9. Hasil pengukuran dari VES PKM_S4 memperlihatkan model resistivitas pada gambar sebelah kiri dan hasil interpretasi pada gambar sebelah kanan. 


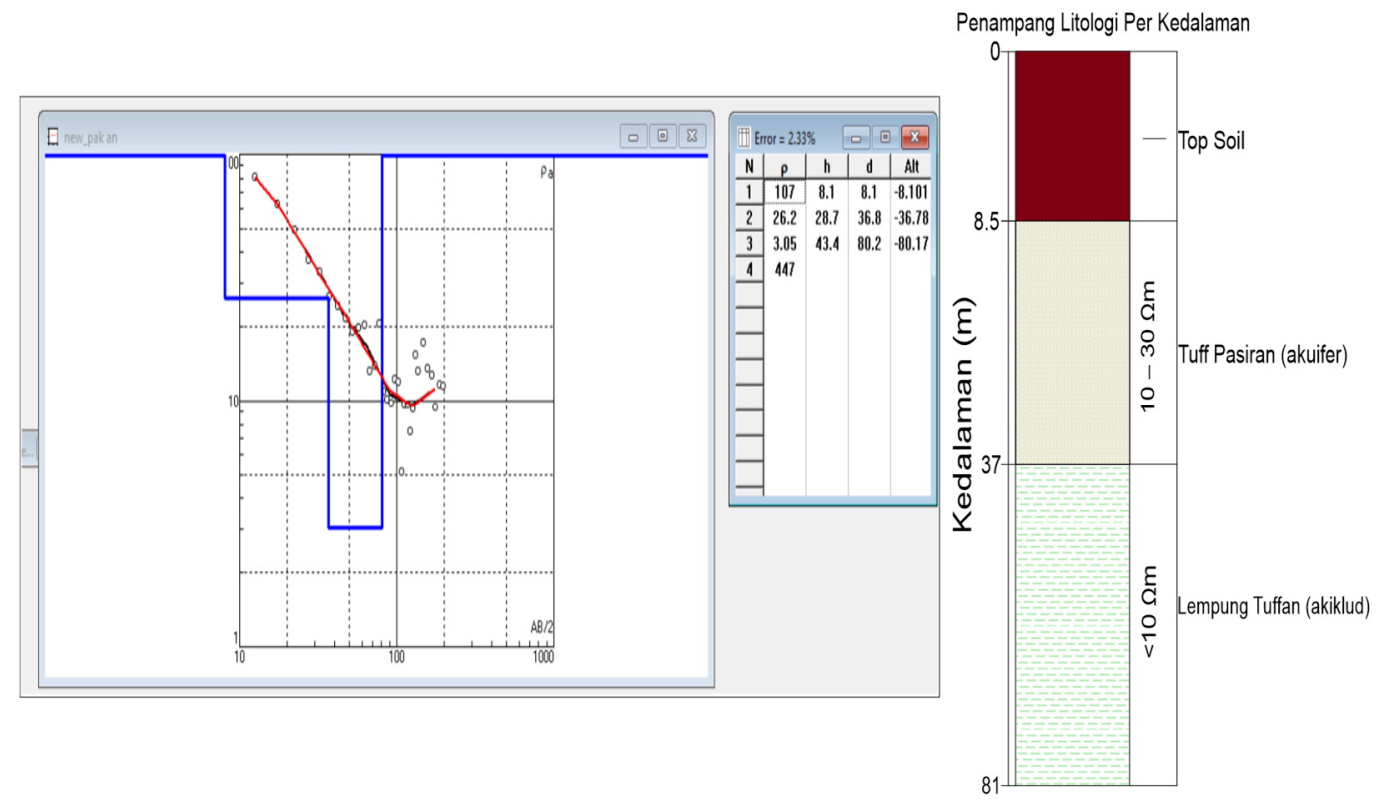

Gambar 10. H asil pengukuran dari VESPKM_S5 memperlihatkan model resistivitas padagambar sebelah kiri dan hasil interpretasi pada gambar sebelah kanan.

\section{KESIMPULAN}

Berdasarkan pada hasil nilai resistivitas yang diperoleh dari pengukuran VES di Dusun Jarisari terdapat kedalaman akuifer yang berbeda di setiap lokasi pengukuran. Nilai resistivitas untuk akuifer berkisar antara 10-30 Ohm.m. Pada titik VESPKM_S1,PKM_S2 dan PKM_S3 keberadan zona akuifer pada kedalaman 7.5-22 meter dan ketebalan berkisar antara 12.6-14.6 meter dengan material tuf pasi ran. Pada titik VESPKM_S4 yang berada di pemukiman warga, ditemukan adanya lapisan batuan tuf pasiran yang diidentifikasi sebagai akuifer pada kedalaman $36 \mathrm{~m}$. Sedangkan untuk titik VES PKM_S5, terlihat adanya kemiripan dari hasil penampang resistivitas yang didapatkan dengan titik VES PKM_S1, PKM_S2 dan PKM_S3. Pada titik ini diperoleh ketebalan akuifer berkisar 28.7 meter pada kedalaman 8.5 meter dengan batuan tuf pasiran.

\section{UCAPAN TERIMA KASIH}

Kami mengucapkan terima kasih kepada semua pihak yang telah mendukungan suksesnya penelitian ini dan bantuan ITERA
Friendly sehingga penelitian ini dapat dilaksanakan.

\section{DAFTAR PUSTAKA}

Aizawa, T. (2014). Application Manual of Geophysical Methods to Engineering and Environmental Problems. EAGE Publications.

A smadi, S. \& Suharno, S. K. M. (2012). Dasar-Dasar Teknologi Pengolahan Air Limbah. Yogyakarta: Gosyen Publishing.

Hendrajaya, L., \& Idham, A. (1990). Geolistrik Tahanan Jenis, Monografi: Metoda Eksplorasi. Laboratorium Fisika Bumi, ITB.

Hewaidy, A. G. A., El-M otaal, E. A., Sultan, S. A., Ramdan, T. M., El khafif, A. A., \& Soliman, S. A. (2015). Groundwater Exploration Using Resistivity And Magnetic Data At The N orthwestern Part of The Gulf of Suez, Egypt. Egyptian Journal of Petroleum, 24(3), 255-263. https://doi.org/10.1016/j.ejpe.2015.07.010

Loke, M. H. (2016). Tutorial: 2-D and 3-D Electrical Resistivity Survey. Springer.

M angga, S. A., A mirudin, Suwarti, T., Gafoer, S., \& Sidarto. (1993). Geological Map of The Tanjungkarang Quadrangle, Sumatra (1: 250,000), Geological Research and Development Centre, Indonesia (1993). Geological Research and Development Centre. 
M ohamaden, M.I.I., W ahaballa, A., \& El-Sayed, H. M. (2016). Application of electrical resistivity prospecting in waste water management: A case study (Kharga O asis, Egypt). Egyptian Journal of Aquatic Research, 42(1), 33-39. https://doi.org/10.1016/j.ejar.2016.01.001

Mohamaden, M.I.I., \& Shagar, S. A. (2008). Structural Effect on The Groundwater at The Arish City, North Eastern Part of Sinai Peninsula, Egypt. Egyptian Journal of Aquatic Research, J anuary 2008.

Paembonan, A., D.R. Febriansanu, R. E. Sinaga, F. D. Putra, \& V. Rahmanda. (2020). Investigasi Air Tanah Pada Endapan Piroklastik dengan Menggunakan Metode Electrical Resistivity
Imaging (ERI). Gravitasi, 19(1), 1-5. https://doi.org/10.22487/gravitasi.v19i1.15182

Palacky, G. J. (1988). Resistivity Characteristics of Geologic Targets. In Electromagnetic M ethods in Applied

Geophysics. https://doi.org/10.1190/1.9781560802631.ch3

Rizka \& Satiawan, S. (2019). Investigasi Lapisan Akuifer Berdasarkan Data Vertical Electrical Sounding (VES) dan Data Electrical Logging; Studi Kasus Kampus Itera. Bulletin of Science Contribution: GEOLOGY, 17, 91-100.

Robinson, C. (1998). Basics Exploration Geophysics. John W iiley and Sons Inc.

Telford, W. M., Geldart, L. P., \& Sheriff, R. E. (1990). Applied Geophysics. In Applied Geophysics. https://doi.org/10.1017/cbo9781139167932 